\title{
PRIVATIZATION OF THE BRITISH OIL INDUSTRY IN THE 1970s - 1980s
}

\author{
Vitalii G. Shishikin \\ Novosibirsk State Technical University, Novosibirsk, Russian Federation
}

\begin{abstract}
Introduction. The relevance of the subject is proved by the interest in the activity of the fuel and energy complex which remains for Russia one of the economic system donors. In this regard, there is growing interest in the experience of the energy industry development in other states, for example to the oil industry reforms in the Great Britain in the last quarter of the $20^{\text {th }}$ century. Methods and materials. The basis of the research is made by works of foreign authors and sources in English. The complex structure of the object of study determines using general historical techniques and the system approach. Analysis. The research of the evolution of the British oil industry is connected with considering the general economic situation in the country and the dominating ideological attitudes of the United Kingdom authorities concerning the economic system during the post-war period. It is possible to note that British authorities paid close attention to the oil industry. The privatization of oil enterprises, which began in the second half of the 1970s, became a reaction to the changes of the economic situation within the country and in the world. It was the tactical maneuver under the Labourists directed to stabilization of the economic system without its essential updating. The subsequent transformations of the oil industry under the Conservatives were based on the basis of the economic paradigm revision, with the expectation of reducing the state's participation in the ownership of enterprise assets, forming a broad layer of owners, both among small and large holders of securities, as well as strengthening the independence of fuel companies. Results. As a result of the reforms in the market, several fuel companies different in power, continued working. The authorities got an opportunity not only to replenish the budget, but also to fulfill the mechanisms of indirect impact on the oil industry that, on the one hand, allowed to differentiate the spheres of the parties' responsibilities, and on the other hand, to maintain the influence of the state in the strategic segment of economy.

Key words: fuel and energy complex, Great Britain, privatization, economic reforms, oil industry, M. Thatcher, British Petroleum.

Citation. Shishikin V.G. Privatization of the British Oil Industry in the 1970s - 1980s. Vestnik Volgogradskogo gosudarstvennogo universiteta. Seriya 4. Istoriya. Regionovedenie. Mezhdunarodnye otnosheniya [Science Journal of Volgograd State University. History. Area Studies. International Relations], 2020, vol. 25, no. 1, pp. 218-228. (in Russian). DOI: https://doi.org/10.15688/jvolsu4.2020.1.18
\end{abstract}

УДК 338.2

Дата поступления статьи: 21.09.2018

ВВК 63.3(4Анг)

Дата принятия статьи: 26.12.2018

\section{ПРИВАТИЗАЦИЯ БРИТАНСКОЙ НЕФТЯНОЙ ОТРАСЛИ В 1970-1980-x ГОДАХ}

\author{
Виталий Геннадьевич Шишикин \\ Новосибирский государственный технический университет, г. Новосибирск, Российская Федерация
}

Аннотация. Актуальность темы обосновывается интересом к деятельности топливно-энергетического комплекса, который остается для России одним из доноров экономики. В связи с этим возрастает интерес к развитию ТЭК других государств, например, реформам нефтяной отрасли Великобритании в последней четверти ХХ века. Основу исследования составляют тексты зарубежных авторов и источники на английском языке. Сложная структура объекта изучения определяет использование общеисторических методов и системного подхода. Исследование эволюции британской нефтяной отрасли связано с рассмотрением общей экономической ситуации в стране и доминирующих идейных установок властей Соединенного Королевства в отношении хозяйственной системы в послевоенный период. Можно отметить, что британские власти уделяли пристальное внимание нефтяной отрас- 
ли. Приватизация нефтяных предприятий, начатая во второй половине 1970-х гг, стала реакцией на изменение экономической ситуации внутри страны и в мире. При лейбористах это было тактическим маневром, направленным на стабилизацию хозяйственной системы без ее существенного обновления. Последующие преобразования нефтяной отрасли при консерваторах строились на основе пересмотра экономической парадигмы с расчетом на сокращение участия государства во владении активами предприятий, формирование широкого слоя собственников как среди мелких, так и крупных держателей ценных бумаг, а также усиление самостоятельности топливных фирм. В результате реформ на рынке продолжили работу несколько разных по мощности топливных компаний. Власти же получили возможность не только пополнить бюджет, но и отработать механизмы косвенного воздействия на нефтяную отрасль, что, с одной стороны, позволило разграничить сферы ответственности сторон, а с другой - сохранить влияние государства в стратегическом сегменте экономики.

Ключевые слова: топливно-энергетический комплекс, Великобритания, приватизация, экономические реформы, нефтяная отрасль, М. Тэтчер, British Petroleum.

Цитирование. Шишикин В. Г. Приватизация британской нефтяной отрасли в 1970-1980-х годах // Вестник Волгоградского государственного университета. Серия 4, История. Регионоведение. Международные отношения. - 2020. - Т. 25, № 1. - C. 218-228. - DOI: https://doi.org/10.15688/jvolsu4.2020.1.18

Введение. Интерес к проблемам развития ТЭК возрос в связи с кризисом, охватившим российскую экономику, динамизм которой в настоящее время во многом зависит от мирового спроса на топливные ресурсы. В период высоких цен на нефть отечественная хозяйственная система в целом успешно преодолевала трудности за счет перенаправления средств, получаемых от ТЭК, в другие сектора экономики. Падение цен на ресурсы привело к возобновлению споров о необходимости структурных преобразований, затрагивающих в том числе и топливно-энергетический сектор.

Изучение опыта реформ ТЭК зарубежных стран является важным предварительным условием модернизации нефтегазовой отрасли России. Особого внимания заслуживают государства, обладающие запасами топливных ресурсов и развитым энергетическим сектором. Показателен пример Великобритании, где в последней четверти XX - начале XXI в. шел поиск оптимальной модели развития ТЭК и схем его взаимодействия с государством. Одним из ключевых моментов являлась серия мероприятий в 1970-1980-х гг. по адаптации нефтяной отрасли к работе в меняющихся экономических условиях. Данная статья посвящена выявлению ключевых характеристик реформ нефтяного сектора Великобритании в указанный период.

Методы и материалы. Исследование проблем развития современного британского ТЭК целесообразно проводить в рамках истории, экономики, регионоведения и др. Необходимо применять как традиционные мето- ды исторической науки, так и приемы междисциплинарных исследований. В работе используется историко-генетический метод, который помогает реконструировать механизмы деятельности нефтяной отрасли в период преобразований. Указанный метод также применяется при изучении действий разных кабинетов Великобритании в отношении рассматриваемой отрасли. С помощью историко-сравнительного метода изучаются проблемы британских нефтяных компаний, при этом выявляются общее и особенное в их развитии в годы реформ. В этой связи хронологические рамки работы несколько расширены, что позволяет проанализировать причины и предпосылки приватизации британской нефтяной отрасли. Реформы рассматриваются через призму отдельных компаний, так как в каждом конкретном случае имел место особый набор факторов, повлиявших на изменение их статуса. Необходимым условием является применение общенаучных методов, в том числе анализа и синтеза, индукции и дедукции, описания и объяснения. Эти методы выступают в качестве конкретных познавательных инструментов, позволяя достичь поставленной цели.

В качестве источников используются документы на английском языке. В первую очередь к таковым относится нормативноправовая база по развитию нефтяной отрасли Великобритании в исследуемый период. Важно отметить, что законодательные акты, используемые в работе, могут касаться развития и других секторов ТЭК. В статье также анализируются делопроизводственные мате- 
риалы - документы партий, стенограммы дебатов в парламенте Соединенного Королевства, а также аналитические отчеты. Важной является информация с официальных сайтов британских нефтяных компаний с данными об их деятельности в разные периоды времени. В качестве источника выступают также новостные тексты, где идет речь об изменениях в нефтяной отрасли Великобритании.

Британский ТЭК является предметом исследования российских и зарубежных авторов. Работ по проблемам развития нефтяного комплекса Соединенного Королевства на русском языке мало. В книге «Энергетические субсидии в современном мире. Страны “Группы двадцати”» авторы среди прочих анализируют работу британского ТЭК, затрагивая ключевые проблемы, стоящие перед ним, и рассматривают меры государства по стимулированию развития энергетического сектора (в том числе нефтедобычи) на современном этапе [3]. Н. Корниенко изучает административные и налоговые механизмы британских властей в отношении нефтяников, которые помогают добиваться сбалансированных выплат, выгодных государству и топливным компаниям [1].

Список работ зарубежных исследователей, посвященных британской нефтяной отрасли, гораздо шире. Необходимо упомянуть лишь те, которые в большей степени относятся к указанной тематике. В работе К. Роудса, Д. Хью и Л. Батчера изучены вопросы приватизации предприятий британского госсектора, среди которых были и нефтяные компании. Авторы охарактеризовали цели, методы и масштабы реформ, направленных на формирование независимых предприятий во многих отраслях британской экономики, в том числе и ТЭК [16]. В работе П. Пирсона и Д. Уотсона речь идет о реформе ТЭК Великобритании, ставшей отражением новой философии властей в отношении национальной экономики. По мнению авторов, приватизация энергетики закрепила новый порядок взаимодействия властей с топливными компаниями и стала отправной точкой для внедрения инноваций в ТЭК [14]. В работе С. Хупс описываются предпосылки и комплекс проблем, связанных с продажей нефтяных активов британскими властями. Исследователь указывает, что после приватизации ставшие частными компании продолжили успешное развитие на энергетическом рынке [10].

Анализ. Нефтяная отрасль Великобритании с момента зарождения находилась под пристальным вниманием властей. Накануне Первой мировой войны Первый лорд Адмиралтейства У. Черчилль предложил перевести флот Великобритании с угля на жидкое топливо, а также приобрести акции «Англо-Персидской нефтяной компании» (Anglo-Persian Oil Company; с 1935 г. - Anglo-Iranian Oil Company («Англо-Иранская нефтяная компания»), a c 1954 г. - British Petroleum («Бритиш Петролеум»)), которая в тот момент находилась на грани банкротства [8]. Нефтяная отрасль страны таким образом оказалась под опекой государства, что было выгодно обеим сторонам. «Англо-Персидской нефтяной компании» обеспечили заказы на поставки топлива и финансовую подушку на случай трудностей, а власти, помимо прочего, получили проводника британских интересов в тех регионах мира, где работала компания. Кроме того, соглашение с властями позволило компании сохранить независимость от англо-голландской «Ройял Дач Шелл» (Royal Dutch Shell), которая в этот период расширяла влияние на нефтяном рынке.

Деятельность нефтяных компаний развивалась в целом успешно, несмотря на экономический кризис и Вторую мировую войну. На это указывает и то, что власти не решились национализировать их после завершения войны, как это произошло со многими отраслями британской экономики, в том числе с угледобычей (1946 г.) и газовой сферой (1948 г.). Одним из факторов сохранения независимости было то, что «Ройял Дач Шелл» и «АнглоИранская нефтяная компания» работали на международной арене. Изменения в структуре руководящих органов компаний могли повлиять на их взаимодействие с зарубежными партнерами, вызвав обеспокоенность на мировом уровне [2, с. 51].

На протяжении тридцати лет в британской элите сохранялся консенсус по вопросам развития экономики. Результаты проведенной в первые послевоенные годы национализации не оспаривались ни консерваторами, ни лейбористами. На единодушие партий влияло и 
то, что с 1948 г. ВВП страны неуклонно увеличивался. Средние темпы роста в 19481973 гг. составили 3,39 \% в год. Лишь в 1974 г. впервые с 1947 г. произошло сокращение ВВП Великобритании на 2,28 \%, а в 1975 г. - на $1,46 \%$ [18], что было связано с мировой экономической ситуацией и топливным кризисом, затронувшим развитые страны, которые закупали нефть на Ближнем Востоке. В результате свертывания поставок из нефтедобывающих стран средняя цена на нефть выросла с 2,7 долл. за баррель в 1973 г. до 11 долл. в 1974 году. В последующие годы цены на нефть не опускались ниже 10 долл. за баррель [5]. Топливный кризис стал своеобразным водоразделом для развития британской нефтяной отрасли. В 1948 г. потребление нефти на внутреннем рынке страны составляло 14,3 млн т (10\%) от общего объема используемых топливных ресурсов в 142,7 млн т нефтяного эквивалента. В 1958 г. показатели увеличились до 40,6 млн т $(23,7 \%)$, из 171,1 млн т, в 1968 г. потребление нефти выросло до 89,7 млн т $(44,7 \%)$ при общем потреблении 200,4 млн т нефтяного эквивалента. В 1978 г. Великобритания потребляла 97 млн т нефти $(43,8 \%)$ из 221,6 млн т нефтяного эквивалента, используемого в стране. Нефть заняла прочные позиции на внутреннем рынке, потеснив уголь, объемы которого в энергетическом балансе страны за указанный период сократились со 128 до 73,3 млн т нефтяного эквивалента. При этом в 1948-1968 гг. импорт нефти вырос с 4,7 до 82,6 млн т, а в 1973 г. достиг пика в 115,5 млн тонн. Таким образом, в это период большая часть нефти, используемая в британской экономике, была привозной. Разработка месторождений Северного моря позволила снизить импорт до 68, 1 млн т в 1978 г. (около $2 / 3$ внутреннего потребления). Минимум был достигнут в 1983 г. - 30,3 млн т, после чего снова начался рост импорта нефти [7, с. 6, 20-21]. Рост собственной нефтедобычи позволил Великобритании занять одно из ведущих мест в ЕЭС, сделав ее донором для других членов Сообщества.

При проведении экономической политики власти Великобритании учитывали особое положение страны в ЕЭС, стремясь адаптировать национальное хозяйство к изменяю- щейся мировой энергетической ситуации и смягчить последствия топливного кризиса для внутреннего рынка. С этой целью были проведены переговоры с «Бритиш Петролеум» и «Ройял Дач Шелл» о дополнительных поставках топлива, но нефтяники отказали в помощи. Аргументы компаний строились на том, что перенаправление поставок на внутренний рынок может повлиять на договоренности с зарубежными партнерами. Неудачный результат переговоров указывал на фактическое бессилие британских властей во взаимоотношениях с нефтяными компаниями, несмотря на то, что большая часть акций «Бритиш Петролеум» принадлежала государству, а 40 \% ценных бумаг «Ройял Дач Шелл» находились во владении британских акционеров [10, с. 42-43].

Сложный период в британской экономике совпал с трудностями нефтяных компаний, которые столкнулись с препятствиями на международной арене. Например, «Бритиш Петролеум» пришлось свернуть деятельность в Ливии, Иране и Кувейте. В 1970-х гг. власти этих государств заявили о национализации британских активов [11]. Серьезное сокращение влияния и снижение добычи нефти на севере Африки и Ближнем Востоке подтолкнуло «Бритиш Петролеум» к диверсификации деятельности в рамках специализации, а также поиску и освоению месторождений в других регионах.

Пример Великобритании в период экономического кризиса 1970-х гг. показывает, что наличие в стране нефтяных компаний не гарантирует властям и гражданам государства стабильности на внутреннем топливном рынке. Даже если нефтяники работают под эгидой властей, нет полной уверенности в том, что они поставят в приоритет интересы государства и его граждан, а не отдадут предпочтение собственной выгоде, объясняя это конъюнктурными факторами, экономической целесообразностью или международными договоренностями. В большей степени это относится к госкомпаниям, имеющим возможность прикрываться его именем, но предпочитают «работать на себя». Конфликт интересов приводит к тому, что выясняется ограниченность арсенала властей в отношении крупных компаний, которые должны блюсти национальные интересы, а на деле больше заботятся о сво- 


\section{ВЛАСТЬ И ОБЩЕСТВО}

их прибылях, но при этом ожидают, что в трудные времена власти помогут им.

Проблема преодоления топливного кризиса отразилась в дискуссии, во время которой высказывалась точка зрения о необходимости усиления контроля над «Бритиш Петролеум» через повышение доли государства в акционерном капитале компании. Однако в итоге власти решили в качестве компенсационной меры сформировать в 1975 г. «Британскую национальную нефтяную корпорацию» (British National Oil Corporation). В Акте «О нефтяных и подводных трубопроводах» идет речь о новой организации, которая должна обеспечить властям долю в добыче нефти и газа на территории Соединенного Королевства. Фактически государство в ответ на трудности, связанные с поставками энергоносителей, а также демарши нефтяных компаний, создало дополнительную структуру, способную выполнять весь спектр работ, связанных с обнаружением, добычей и реализацией топливных ресурсов (нефть и газ), удовлетворяя потребности страны. При этом серьезная роль отводилась контролю над развитием нефтяной отрасли через инвестиции, лицензионное обеспечение, администрирование, консультирование и другие механизмы, обеспечивающие стабильное развитие добычи в Северном море [15].

Можно отметить, что в ответ на кризисные явления в энергетической сфере кабинет Г. Вильсона использовал методы, которые применялись в рамках избранной после Второй мировой войны экономической стратегии. Ее специфика сводилась к тому, что для преодоления трудностей в проблемной отрасли создавалась хозяйственная структура, выступающая в качестве интерфейса государства, в данном случае в нефтяной сфере. В итоге влияние государства в экономической жизни страны росло, затраты и социальные обязательства по отношению к работникам расширялись. Эффективность деятельности подобной структуры на первых порах возрастала, но имела ограничения для развития, а потому на определенном этапе начинала стагнировать и вызывать закономерную критику. С помощью избранных мер изменить ситуацию в нефтяной отрасли в короткие сроки не представлялось возможным, что подталкивало власти искать новые методы воздействия на топливные компании и идти на дополнительные финансовые траты.

В 1977 г. властям пришлось продать $17 \%$ акций «Бритиш Петролеум» за 560 млн фунтов стерлингов. Это позволило пополнить государственный бюджет, но что более важно - получить транш от МВФ для стабилизации финансов, пострадавших в результате кризисных явлений. Государству требовалось нивелировать негативные последствия в социально-экономической системе, среди которых были не только повышение цены на нефть, но и забастовка шахтеров в 1974 году. Массовые протесты горняков способствовали отставке кабинета консерваторов Э. Хита и прихода к власти лейбористов во главе с Г. Вильсоном $[16$, с. 2,14$]$. В отличие от консерваторов лейбористы не планировали проводить радикальные преобразования в ТЭК, сохраняя государственные дотации и разветвленную систему социального обеспечения. На тот момент приватизация части «Бритиш Петролеум» носила тактический характер. Кабинет лейбористов не был готов расстаться с активами компаний, которые находились в собственности государства, придерживаясь принципов индустриальной политики, малоэффективных в условиях структурных изменений мировой экономики. При этом частичная приватизация нефтяного гиганта не решала проблемы ни хозяйственной системы Великобритании, ни «Бритиш Петролеум», позиционирование которой не претерпело изменений.

Находящиеся в тот момент в оппозиции консерваторы выступали за то, что энергетика будет лучше развиваться, если выйдет изпод опеки государства [4]. После прихода к власти в 1979 г. консервативного кабинета М. Тэтчер были обозначены новые ориентиры в экономической политике Великобритании. Власти взяли курс на последовательное сокращение доли государства в хозяйственной системе страны за счет постепенной продажи активов компаний, национализированных после войны. Необходимо отметить, что запрос на расширение доли и самостоятельности частного сектора был и со стороны населения, в том числе контингента работников госпредприятий [10, с. 54-55]. 
Среди компаний, подлежащих распродаже, были крупные пакеты акций и предприятий нефтяной сферы. В качестве одного из мотивов реформирования отрасли выступала переориентация деятельности британских нефтяных компаний с Ближнего Востока на Северное море, где в 1960-х гг. проводилась разведка, а с середины 1970-х гг. началась разработка месторождений. Важным фактором стало и то, что у нефтяников сохранялась высокая степень автономии, и их интересы не всегда совпадали с приоритетами государства. В связи с этим требовалось установить более четкое распределение полномочий, прибыли и степени взаимодействия. Речь также шла о том, чтобы повысить эффективность деятельности отрасли, которая действовала на внутреннем рынке и участвовала в проектах на территории других стран.

Уже в октябре 1979 г., то есть менее чем через полгода после прихода к власти, кабинет М. Тэтчер инициировал продажу еще одного пакета акций «Бритиш Петролеум» в $5 \%$, выручив 276 млн фунтов стерлингов. В 1981 г. власти передали права на $6 \%$ акций за 8 млн фунтов стерлингов. В 1983 г. была продана доля в 7 \% за 543 млн фунтов стерлингов [16, с. 14]. Государство последовательно сокращало свое участие в капитале компании. При этом примерно равные пакеты акций могли отличаться по цене, что было связано с комплексом причин. После реализации пакета в 1979 г. у властей осталось менее $50 \%$ акций «Бритиш Петролеум». Последующие продажи довели объем владения до одной трети, что позволяло кабинету сохранять влияние на компанию. В 1981 и 1983 гг. продажи акций проводились в период кризиса, когда цены на нефть резко пошли вниз. Возвращение цены на нефть до отметки рубежа 1970-1980-х гг. пришлось ждать больше четверти века [14, с. 4].

Созданная властями в 1975 г. «Британская национальная нефтяная корпорация» за первые годы нахождения у власти консерваторов претерпела трансформации, которые были изначально заложены в ее структуру. Фактически Корпорация объединяла в себе функции хозяйствующего субъекта, призванного эффективно работать на рынке, и управленческой организации, координирующей неф- тедобычу. В 1982 г. согласно Акту «О предприятиях нефти и газа» произошло разделение Корпорации [12]. За «Британской национальной нефтяной корпорацией», оставшейся в собственности властей, сохранились функции продавца топлива, что отвечало задачам государства по контролю над развитием внутреннего рынка нефти. Та часть компании, которая занималась разведкой и добычей, была выделена в общество с ограниченной ответственностью «Бритойл» (Britoil). При этом «Британская национальная нефтяная корпорация» на момент разделения контролировала в Северном море девять месторождений нефти и одно месторождение газа, добывая 7 \% североморской нефти и контролируя в общей сложности $60 \%$ нефти в регионе [10, с. 61].

Работа над документацией по приватизации Корпорации началась в 1980 г. еще до ее разукрупнения. Первоначально у властей не было четкого понимания того, как вывести компанию из-под государственной опеки. Предлагалось реализовывать облигации через почтовые отделения, а также управлять акциями с помощью инвестиционного траста и их постепенной продажей. В ходе приватизации была задействована так называемая «золотая акция», которая давала кабинету консерваторов возможность использовать ее как механизм компромисса в отношениях с лейбористкой оппозицией, выступавшей с критикой продажи госкомпаний, так и при взаимодействии с акционерами [10, с. 75-82]. «Золотая акция» позволяла властям контролировать деятельность компании и после продажи активов. Фактически этот инструмент защищал приватизированную компанию от недобросовестных инвесторов, сохраняя за государством на переходный период возможность участия в работе предприятий. Тем самым в рамках рыночной системы формировался механизм, сдерживающий конкуренцию, сохраняя серьезные позиции за государством.

В конце 1982 г. 51 \% акций «Бритойл» был продан за 627 млн фунтов стерлингов, а еще через три года власти реализовали на рынке оставшиеся $49 \%$ акций за 426 млн фунтов стерлингов. При этом 0,2 \% акций достались работникам компании, а другие были распределены между несколькими сотнями фондов и инвестиционных учреждений [16, с. 14, 22]. 
«Британская национальная нефтяная корпорация» была преобразована в «Агентство по нефти и трубопроводам» (Oil and Pipelines Agency). Новой структуре перешли функции по решению вопросов, связанных с нефтяными ресурсами, трубопроводами и хранилищами [13]. На момент формирования под контролем Агентства находилось около трети североморской нефти. Таким образом власти смогли реализовать на рынке объемный пакет акций (на тот момент это была крупнейшая приватизационная сделка в Великобритании) и создать ряд рычагов давления на нефтяников, чтобы избежать повторения ситуации середины 1970-х гг. с нестабильностью цен на энергоресурсы и демаршами топливных компаний.

Скромные для «Бритойл» показатели цены при продаже объясняются несколькими причинами. За столь короткий промежуток времени компания не успела сделать себе имя, оставаясь в тени «Бритиш Петролеум» и «Ройял Дач Шелл». Сама структура Корпорации была такой, что полностью реализовать ее на рынке оказалось сложно, поэтому сначала пришлось создавать автономные подразделения, а после разукрупнения продавать по частям, хотя еще до разделения «Британской национальной нефтяной корпорации» звучали голоса о сохранении ее единства. Более того, приватизация проходила в условиях колебаний цен на нефть, что оказывало влияние на стоимость бумаг.

После продажи всего пакета акций власти, как и планировалось, продолжали контролировать «Бритойл» за счет сохранения «золотой акции». По существу в 1984-1988 гг., опекая «Бритойл», кабинет М. Тэтчер «держал руку на пульсе» всей нефтяной отрасли, стремясь не допустить ее кризиса в период падения цен на энергоресурсы, переформатирования рынка и выстраивания новой системы взаимодействия государства и частника. Адаптационный период завершился в 1988 г. после перехода большей части акций «Бритойл» во владение «Бритиш Петролеум». Перед торгами власти не собирались вмешиваться в дела бизнеса, но когда стало известно, что на «Бритойл» претендует компания «Арко» (Arco - Atlantic Richfield), мнение изменилось. Было заявлено о том, что государство исполь- зует «золотую акцию», чтобы повлиять на сделку. В итоге «Арко» отступила, а «Бритиш Петролеум» купила «Бритойл» [16, с. 14, 22]. Объявив о возможности использовать «золотую акцию», правительство дало понять, что не выступит противником поглощения одной нефтяной компании другой, если это помогает развитию отрасли в целом, а не является спекуляцией. Это был один из механизмов, позволявший властям направлять работу отрасли, контролируя степень ее монополизации и распределения активов.

Пример «Бритойл» указывает на эволюцию британского нефтяного рынка, последовательного перехода от превалирующего положения государства к независимым компаниям. При этом рынок Великобритании закрепил ведущую роль крупных игроков. Для того чтобы избежать полной монополизации власти в ходе самой приватизации предприняли ряд мер для перераспределения ценных бумаг в пользу как крупных собственников, так и мелких держателей акций. Помимо высвобождения государства от активов компаний, кабинет решал задачу по созданию широкой общественной базы поддержки за счет развития частного предпринимательства и увеличения числа мелких собственников - акционеров национальных компаний [4].

В связи этим интересен пример нефтяной компании «Энтерпрайз Ойл» (Enterprise Oil), приватизированной параллельно с «Бритойл». Она была создана в 1983 г. в качестве подразделения государственной монополии «Британской газовой корпорации» (British Gas Corporation), занимавшейся разработкой газовых и нефтяных месторождений. К моменту продажи у компании было пять нефтяных полей $[16$, с. 14, 29]. Летом 1984 г. власти выставили акции «Энтерпрайз Ойл» на торги небольшими пакетами во избежание их захвата или поглощения крупными компаниями, а также оставили за собой владение «золотой акцией». Речь шла о том, что одно физическое или юридическое лицо не могло купить более $10 \%$ акций «Энтерпрайз Ойл», которая должна стать независимой нефтяной компанией. По итогам размещения ценные бумаги компании перешли в руки широкой группы собственников, в том числе 150-200 организаций, включая пенсионные фонды, 13 тыс. мелких дер- 
жателей, среди которых были работники компании. Государство при этом выручило 392 млн фунтов стерлингов [9].

Еще одна сделка, приведшая к высвобождению государства от нефтяных активов, была связана с месторождением «Витч Фарм» (Wytch Farm), принадлежавшим «Британской газовой корпорации». Руководство монополии сопротивлялось продаже актива, указывая на то, что независимая оценка его цены (160-165 млн фунтов стерлингов) гораздо ниже реальной стоимости (450 млн фунтов стерлингов). Помимо разницы в цене менеджеры компании говорили о попрании национальных интересов, возможном возникновении экологических проблем и др. В итоге удалось договориться о том, что активы будут переданы «Дорсет Групп» (Dorset Group) - консорциуму из пяти независимых компаний. Изза разногласий между руководством компании и властями сделка растянулась на $1983-$ 1984 годы. Сторонам удалось прийти к компромиссу - покупатели первоначально выплачивали 85 млн фунтов стерлингов, а вторую часть в размере 130 млн фунтов стерлингов после того, как добыча на «Витч Фарм» достигнет 20 тыс. баррелей в сутки. На момент продажи месторождение давало всего 4,5 тыс. баррелей в сутки, но имело возможности расширения до 40 тыс. баррелей [9, с. 85-87]. В итоге оператором «Витч Фарм» в 1984 г. стала «Бритиш Петролеум» [20], которая последовательно аккумулировала нефтяные активы приватизированных предприятий и одновременно готовилась к выходу из-под опеки государства. Фактически власти передавали нефтяные активы в пользование компании, находящейся под государственным влиянием и таким образом давали отрасли возможность и время адаптироваться к работе в качестве полунезависимого хозяйствующего субъекта.

Ключевым в ходе преобразований нефтяной отрасли стала продажа наиболее крупного пакета акций «Бритиш Петролеум», которая состоялась в 1987 году. Во время консультаций властей и руководителей компании было отклонено предложение о «золотой акции». При этом власти озвучили намерения реализовать весь пакет разом и на разных площадках, но менеджеры «Бритиш Петролеум» настаивали на разделении продаж и склонялись к тому, что акции должны остаться в Великобритании [10, с. 94-97]. В итоге было решено распродать оставшиеся у государства $32 \%$ бумаг одновременно в Великобритании, США, Японии, Канаде и континентальной Европе, чтобы избежать затоваривания и, соответственно, снижения цен на акции [6]. Продажи проходили в октябре 1987 г. во время падения рынка и принесли более 5,5 млрд фунтов стерлингов [16, с. 14]. На тот момент это была крупнейшая сделка по приватизации в Великобритании, которая привела к высвобождению государства от активов топливных компаний и формированию новой системы отношений между властями и нефтяниками.

Можно отметить, что топливный кризис середины 1970-х гг., а также развитие мировой экономики стали индикаторами, указывающими на то, что государство должно изменить матрицу взаимоотношений с крупными компаниями, дать им больше возможностей для реализации своих целей и выстроить четкую систему взаимодействия. Приватизация позволяла закрепить дистанцию и распределить полномочия, а также финансовые вопросы. Об ее эффективности можно судить по последующей успешности нефтяных компаний. Так, в 2002 г. «Энтерпрайз Ойл» была куплена «Ройял Дач Шелл» за 3,5 млрд фунтов стерлингов, то есть через 20 лет цена компании выросла почти в девять раз [17]. «Бритиш Петролеум» в настоящее время находится на 36-м месте списка Forbes среди крупнейших публичных компаний и на 6-м по рыночной стоимости среди нефтегазовых корпораций мира [19]. Освобождение государства от нефтяных активов не привело к кризису отрасли, а дало ей импульс для развития в новых экономических условиях.

Результаты. На начальном этапе, в 1970-х гг., приватизация британской нефтяной отрасли являлась реакцией властей на изменение экономической ситуации в стране и мире. Стремление сохранить статус-кво, сложившийся за несколько десятилетий, стабилизировало хозяйственные отношения, но не имело перспектив для развития отрасли. В 1980-х гг. вектор реформ изменился и был нацелен на качественное обновление экономики страны, что сопровождалось высвобождением государства от акций нефтяных компаний, вело к пополнению бюджета и перераспределению активов 
между держателями ценных бумаг, то есть формированию широкой базы собственников. Крупные владельцы акций придавали рынку устойчивость, средние и мелкие сдерживали его монополизацию и повышали гибкость. Одновременно власти применяли меры косвенного воздействия на отрасль, формируя промежуточные управленческие структуры или используя механизм «золотой акции», что позволило разграничить ответственность сторон в нефтедобыче и сохранить влияние государства на отрасль. Эта схема стала отражением новой философии и реакцией государства на изменения в экономике, требующей от властей более гибкого подхода при управлении хозяйственной системой, в противовес прямому воздействию. Последнее сдерживает развитие экономики в целом и отдельных ее секторов, консервирует сложившиеся отношения между властью и хозяйствующими субъектами, ограничивает возможности по реагированию на происходящие изменения.

\section{СПИСОК ЛИТЕРАТУРЫ}

1. Корниенко, Н. Налогообложение нефтегазовой промышленности: опыт Великобритании / Н. Корниенко // Экономико-политическая ситуация в России. -2008 . - № 5. - С. 43-46.

2. Шишикин, В. Г. Особенности национализации британского ТЭК в середине XX в. / В. Г. Шишикин // Региональные процессы в глобализирующемся мире : сб. науч. работ преподавателей, аспирантов и магистрантов / отв. ред. О. В. Зиневич, В. Г. Шишикин. - Новосибирск : Изд-во НГТУ, 2017. - C. 50-55.

3. Энергетические субсидии в современном мире. Страны «Группы двадцати» / под ред. Л. М. Григорьева, А. А. Курдина. - М. : Асмин Принт, 2014. -400 c.

4. 1979 Conservative Party General Election Manifesto. - Electronic text data. - Mode of access: http://www.conservative-party.net/manifestos/1979/ 1979-conservative-manifesto.shtml (date of access: 10 June 2018).

5. Average annual OPEC crude oil price from 1960 to 2018 (in U.S. dollars per barrel). - Electronic text data. - Mode of access: https://www.statista.com/ statistics/262858/change-in-opec-crude-oil-pricessince-1960 (date of access: 30 December 2018).

6. BP Share Offer (Hansard, 3 November 1987). - Electronic text data. - Mode of access: https://api.parliament.uk/historic-hansard/written- answers/1987/nov/03/bp-share-offer (date of access: 5 August 2018).

7. Digest of United Kingdom Energy Statistics: $60^{\text {th }}$ Anniversary. - Electronic text data. - Mode of access: https://assets.publishing. service.gov.uk/government/ uploads/system/uploads/attachment_data/file/65896/ 1_20090729135638_e dukes60.pdf(date of access: 5 January 2019).

8. Early History - 1909-1924. - Electronic text data. - Mode of access: https://www.bp.com/en/ global/corporate/who-we-are/our-history/earlyhistory.html (date of access: 2 June 2018).

9. Enterprise Oil (Hansard, 28 June 1984). Electronic text data. - Mode of access: https://api. parliament.uk/historic-hansard/commons/1984/jun/28/ enterprise-oil (date of access: 23 July 2018).

10. Hoopes, S. The Privatization of UK Oil Assets 1977-87: Rational Policy-Making, International Changes and Domestic Constraints / S. Hoopes. - L. : [s. 1.], 1994. $-354 \mathrm{p}$.

11. Late Century-1971-1999. - Electronic text data. - Mode of access: https://www.bp.com/en/ global/corporate/who-we-are/our-history/earlyhistory.html (date of access: 7 June 2018).

12. Oil and Gas (Enterprise) Act 1982. - Electronic text data. - Mode of access: http://www.legislation.gov.uk/ ukpga/1982/23/pdfs/ukpga_19820023_en.pdf (date of access: 29 June 2018).

13. Oil and Pipelines Act 1985. - Electronic text data. - Mode of access: http://www.legislation.gov.uk/ ukpga/1985/62/pdfs/ukpga_19850062_en.pdf(date of access: 12 July 2018).

14. Pearson, P. UK Energy Policy, 1980-2010. A history and lessons to be learnt. A review to mark 30 years of the Parliamentary Group for Energy Studies / P. Pearson, J. Watson. - L. : [s. 1.], 2012. -64 p.

15. Petroleum and Submarine Pipelines Act 1975. - Electronic text data. - Mode of access: http: //www.legislation.gov.uk/ukpga/1975/74/pdfs/ukpga_ 19750074_en.pdf(date of access: 14 June 2018).

16. Rhodes, C. Privatisation / C. Rhodes, D. Hough, L. Butcher. - L. : House of Commons Library, 2014. $-42 \mathrm{p}$.

17. Royal Dutch/Shell Will Buy Enterprise Oil of Britain. - Electronic text data. - Mode of access: https: //www.nytimes.com/2002/04/03/business/royal-dutchshell-will-buy-enterprise-oil-of-britain.html (date of access: 23 July 2018).

18. The Bank of England's Three Centuries Macroeconomic Dataset Version 2.3. - 2016. - 30 June. Electronic text data. - Mode of access: http://www. bankofengland.co.uk/research/Documents/datasets/ threecenturies_v2.3.xlsx (date of access: 4 June 2018).

19. The World's Largest Public Companies. 2018 Ranking. - Electronic text data. - Mode of access: https://www.forbes.com/global2000/list/header:market 
Value_sortreverse:true_industry:Oil $\% 20 \% 26 \% 20 \mathrm{Gas} \%$ 20Operations (date of access: 28 August 2018).

20. Wytch Farm Oil Field. - Electronic text data. Mode of access: https://www.nytimes.com/2002/04/03/ business/royal-dutch-shell-will-buy-enterprise-oil-ofbritain.html (date of access: 8 August 2018).

\section{REFERENCES}

1. Kornienko N. Nalogooblozhenie neftegazovoy promyshlennosti: opyt Velikobritanii [Taxation of Oil and Gas Industry: UK Experience]. Ekonomikopoliticheskaya situatsiya $v$ Rossii, 2008, no. 5, pp.43-46.

2. Shishikin V.G. Osobennosti natsionalizatsii britanskogo TEK v seredine XX v. [Features of the Nationalization of the British Fuel and Energy Complex in the Mid $20^{\text {th }}$ Century]. Zinevich O.V., Shishikin V.G., eds. Regionalnye protsessy v globaliziruyushchemsya mire: sb. nauch. rabot prepodavateley, aspirantov $i$ magistrantov [Regional Processes in the Globalizing World. Collection of Scientific Articles of Lecturers, Postgraduate Students and Master Students]. Novosibirsk, Izd-vo NGTU, 2017, pp. 50-55.

3. Grigoryev L.M., Kurdin A.A., eds. Energeticheskie subsidii v sovremennom mire. Strany "Gruppy dvadtsati» [Energy Subsidies in the Modern World. G20 Countries]. Moscow, OOO «Asmin Print» Publ., 2014. 400 p.

4. 1979 Conservative Party General Election Manifesto. URL: http:/www.conservative-party.net/ manifestos/1979/1979-conservative-manifesto.shtml (accessed 10 June 2018).

5. Average Annual OPEC Crude Oil Price from 1960 to 2018 (In U.S. Dollars per Barrel). URL: https:// www.statista.com/statistics/262858/change-in-opeccrude-oil-prices-since-1960/ (accessed 30 December 2018).

6. BP Share Offer (Hansard, 3 November 1987). URL: https://api.parliament.uk/historic-hansard/ written-answers/1987/nov/03/bp-share-offer (accessed 15 August 2018).

7. Digest of United Kingdom Energy Statistics: 60 $0^{\text {th }}$ Anniversary. URL: https://assets.publishing. service.gov.uk/government/uploads/system/uploads/ attachment_data/file/65896/1_20090729135638_ e__ dukes60.pdf (accessed 5 January 2019).
8. Early History - 1909-1924. URL: https: //www.bp.com/en/global/corporate/who-we-are/ourhistory/early-history.html (accessed 2 June 2018).

9. Enterprise Oil (Hansard, 28 June 1984). URL: https:/api.parliament.uk/historic-hansard/commons/ 1984/jun/28/enterprise-oil (accessed 23 July 2018).

10. Hoopes S. The Privatization of UK Oil Assets 1977-87: Rational Policy-Making, International Changes and Domestic Constraints. London, 1994. $354 \mathrm{p}$.

11. Late Century - 1971-1999. URL: https: //www.bp.com/en/global/corporate/who-we-are/ourhistory/early-history.html (accessed 7 June 2018).

12. Oil and Gas (Enterprise) Act 1982. URL: http://www.legislation.gov.uk/ukpga/1982/23/pdfs/ ukpga_19820023_en.pdf(accessed 29 June 2018).

13. Oil and Pipelines Act 1985. URL: http: //www.legislation.gov.uk/ukpga/1985/62/pdfs/ukpga_ 19850062_en.pdf(accessed 12 July 2018).

14. Pearson P., Watson J. UK Energy Policy, 1980-2010. A History and Lessons to Be Learnt. A Review to Mark 30 Years of the Parliamentary Group for Energy Studies. London, 2012. 64 p.

15. Petroleum and Submarine Pipelines Act 1975. URL: http://www.legislation.gov.uk/ukpga/1975/ 74/pdfs/ukpga_19750074_en.pdf (accessed 14 June 2018).

16. Rhodes C., Hough D., Butcher L. Privatisation. London, House of Commons Library, 2014. 42 p.

17. Royal Dutch/Shell Will Buy Enterprise Oil of Britain. URL: https://www.nytimes.com/2002/04/03/ business/royal-dutch-shell-will-buy-enterprise-oil-ofbritain.html (accessed 23 July 2018).

18. The Bank of England's Three Centuries Macroeconomic Dataset Version 2.3 - 30 June 2016. URL: http://www.bankofengland.co.uk/research/ Documents/datasets/threecenturies_v2.3.xlsx (accessed 4 June 2018).

19. The World's Largest Public Companies. 2018 Ranking. URL: https://www.forbes.com/global2000/ list/\#header:marketValue_sortreverse:true_industry: Oil\%20\%26\%20Gas\% $\%$ 20Operations (accessed 28 August 2018).

20. Wytch Farm Oil Field. URL: https://www. nytimes.com/2002/04/03/business/royal-dutch-shellwill-buy-enterprise-oil-of-britain.html (accessed 8 August 2018). 


\section{Information About the Author}

Vitalii G. Shishikin, Candidate of Sciences (History), Associate Professor, Department of International Affairs and Regional Studies, Novosibirsk State Technical University, Prosp. K. Marksa, 20, 630073 Novosibirsk, Russian Federation, wital_sh@mail.ru, https://orcid.org/0000-0002-2645-871X

\section{Информация об авторе}

Виталий Геннадьевич Шишикин, кандидат исторических наук, доцент кафедры международных отношений и регионоведения, Новосибирский государственный технический университет, просп. К. Маркса, 20, 630073 г. Новосибирск, Российская Федерация, wital_sh@mail.ru, https://orcid.org/0000-0002-2645-871X 